\title{
Knowledge and the Mystery of Black Boxes: The Construction of a Techno-scientific-culture in The Case of Digital Maritime Safety
}

Dicky Rezandi Munaf \& Yasraf Amir Pilang

Institut Teknologi Bandung

\begin{abstract}
The growth of knowledge in an institution is highly determined by the cultural system and environment, in which the knowledge is produced, disseminated and appropriated. Knowledge, which is substantially demanded for the continuation of the institution, can only be systematically generated in a good social and cultural environment. Yet, in many cases, there is a kind of "black box" that structurally impedes the production of knowledge, because of incapability of the system in constructing a collective "scientific culture". This paper analyze the techno-scientific system usage in the Indonesia Maritime Security Coordinating Board (IMSCB) worked from 2006-2014. Here, two related systems are responsible for the production of knowledge in the institution, i.e., "techno-science" and "techno-culture". Yet, the capacity of certain institutions in generating useful knowledge is highly determined by the capability of "technoscientific-culture" to open "black boxes", that is capable to reveal and understand the complexity behind natural or social realities: earthquake, Tsunami, flood, traffic jam, chaos or mass violence. Thus a cultural transformation has to be systematically initiated to integrate techno-science and techno-culture, create self-reflectivity of the scientific world, and build "public awareness" about the function, significance and science benefit and technology for community, society and humankind in general.
\end{abstract}

Keywords: knowledge, security, black-box, techno-science, techno-culture, regulation, society

Pertumbuhan ilmu pengetahuan dalam suatu institusi sangat ditentukan oleh sistem budaya dan lingkungan, di mana pengetahuan dihasilkan, disebarluaskan dan disesuaikan. Pengetahuan, yang secara substansial menuntut kelanjutan institusi, hanya dapat dihasilkan secara sistematis dalam lingkungan sosial dan budaya yang baik. Namun, dalam banyak kasus, semacam "kotak hitam" yang secara struktural menghambat produksipengetahuan, karena ketidakmampuan sistem dalam membangun "budaya ilmiah" kolektif. Makalah ini menganalisis penggunaan sistem teknologi ilmiah di Badan Koordinasi Keamanan Maritim 
Indonesia (IMSCB) yang bekerja dari 2006-2014. Di sini, dua sistem terkait bertanggung jawab untuk memproduksi pengetahuan di institusi, yaitu, "techno-science" dan "techno-culture". Namun, kapasitas lembaga-lembaga tertentu dalam menghasilkan pengetahuan yang bermanfaat sangat ditentukan oleh kemampuan "budaya-ilmiah-teknologis" untuk membuka "kotak hitam", yang mampu mengungkapkan dan memahami kompleksitas di balik realitas alam atau sosial: gempa bumi, tsunami, banjir, kemacetan, kekacauan atau kekerasan massal. Jadi, transformasi budaya harus secara sistematis dimulai untuk mengintegrasikan tekno-sains dan tekno-budaya, menciptakan refleksi diri dari dunia ilmiah, dan membangun "kesadaran publik" tentang fungsi, makna dan manfaat sains dan teknologi untuk masyarakat dan manusia secara umum.

Kata kunci: pengetahuan, keamanan, black-box, techno-science, technoculture, regulasi, masyarakat 


\section{Introduction}

Knowledge as a fundamental signifier of human intellectual capacity has never existed in a hollow space. In contrast, it is part of every culture and society, particularly an institution in which it is produced. In term of an institution, knowledge is not only a 'product' of human consciousness, will or desire, but also an institutional product. In other words, knowledge is institutionally and socially constructed. Knowledge can only exist when there is human 'consciousness' and social 'need' to develop, appropriate or give meaning. Hence, knowledge is not merely an epistemological exercise but also social and cultural enterprises. In its social context, there is a notion about "the social construction of knowledge". In this sense, the social structure, mental structure, and cultural value in a society highly determine forms, structures and orientation of knowledge.

It is generally acknowledged that knowledge's 'vehicle' is set in motion when a scientist in a certain institution can answer a scientific question, reveal a mystery and find a genius solution, through his or her genius mind. In contrast, knowledge's machine is deemed 'frozen' and 'buried' in a kind of black box if no one is being motivated to open the box, answer the scientific questions, reveal mysteries or find a solution to problems in the institution. The freeze of knowledge machine may relate to the fact that people have remained dormant in the 'black box' and forgotten 'the key' to open the box. The freeze, however, may not be the result of absence of the right key, but of absence of 'the drive' to find the key. In other words, the cause of the freeze lies in the humans behind the key, to be specific, their consciousness, mentality and mindset.

Evidently, the profile of 'consciousness machine' will determine the growth of knowledge of an institution or society, whether it is productive or unproductive, positive or negative, constructive or destructive. For instance, consciousness controlled by a culture of consumerism will produce a consumer of knowledge, not a producer; consciousness controlled by "industrialization of mind" will produce a condition of commercialization of knowledge; consciousness controlled by a megalomaniac desire will produce knowledge as a part of a human mass destruction; consciousness controlled by the principle of "fatalism" will produce human being as an 'object' of knowledge.

This paper is not so much on science or technology themselves but a study about how knowledge is developed in the so called 'techno-science', and on how knowledge and products of technology construct a culture of an 
institution, namely a 'techno-culture'. Hence, the focus is on the sociocultural dimensions of an institution. The paper in particular highlights certain 'mist', 'veil', 'noise' or 'chaos' behind the production of knowledge, of what is called a 'black-box'. This study elaborates on the role of knowldge and technology-particularly high-technology-in Indonesia Maritime Security Coordinating Board (IMSCB) and how they shape the 'technoscience' and 'techno-culture' of the institution.

\section{Technoscience and National Security}

The development of Indonesian maritime is one of the targets of the current national leadership. These targets should also be accompanied by the development of facilities and infrastructure on sea security and information due to its importance for the maritime society that requires accurate and actual information related to the security of Southeast Asia's waters, including the security in the Indonesian archipelagic sea lanes. This society, both from within and abroad, describes the actual conditions of the maritime security in Southeast Asia, including jurisdictional waters of Indonesia, which are still considered vulnerable to the dangers of terrorism, piracy and violence.

Currently, some countries that join a maritime organization, Crimario (Critical Maritime Routes on the Indian Ocean), through their project, have built and will continue to build some Information Sharing Centers in the countries along the Indian Ocean. The aim of their project is to secure the shipping lanes of their trade to European countries from piracy threats and other marine security threats, as $90 \%$ of the world's trade uses sea transportation. Their efforts and the world's trade data indicate how important the Maritime Security Center is for guarding the world's security and the safety of the shipping lanes and for ensuring the security of the shipping lanes.

In the Presidential Regulation Number 81 Year 2005 concerning the government's work plan for the Year 2005-2025 about the Field of Defense gives a mandate to establish IMSCB as a government agency in charge of the security and safety of the sea, including the command and control, supported by Early Warning System (EWS). EWS is a circuit means of electronic equipment that can monitor Indonesian waters, and the data resulting from the monitoring are then analyzed by experts to generate reports containing some warnings of potential illegal activities and marine 
distresses. The objective of the EWS itself is to perform analysis in the areas relevant to the security, safety, and law enforcement of the sea, provide early warnings on the imminent crises that threaten both the sea security and the national security, build crisis management at sea, both nationally and internationally, by detecting the intents/movements of the enemy or the parties that potentially threaten the security and safety of the sea, and offer the information to formulate the maritime security and protect the classified information.

The government's mandate to establish IMSCB may be achieved if the concept of establishing the national Maritime Security Information Centre (NMIC) is readily set, with the goal of developing the Early Warning System (EWS) based on information and communication technology. The agency apparently suitable to carry out such mandate is IMSCB because it has both the facilities and the infrastructures that have met the minimum IMO's requirements. In addition, this agency has also been serving the public by providing them the EWS report every day at 8 a.m. and 4 p.m. This same EWS report is also sent to the Indonesia's National Military Command Center and National Police Headquarters, which then disseminate the report to public through Indonesia's' naval posts (POSAL), naval bases (LANAL), Port Administrations (ADPEL), and Water Police (POLAIR).

IMSCB has built 11 Regional Coordinating Centers (RCC), 3 Maritime Regional Coordinating Centers (MRCC) and 2 Ground Stations (GS), from Aceh to Papua, all of which are integrated and supported by (a) system of Information and Communication Technology for Early Warning System on sea security and safety; (b) Automatic Identification System (AIS), and (c) Global Maritime Distress Safety and Security System (GMDSS) with a limited range of approximately 50-60 Nm (see IMSCB Roadmap year 20072014, item 1). The above-mentioned MRCC's and RCC's facilities are those used to obtain monitoring data on the ship traffic and detect the conditions of seas in each region of Indonesian archipelagic sea lanes (ALKI). The monitoring technology owned by IMSCB today can be classified as follows: (i) ENC (Electronic Navigation chart, (ii) AIS database (base station); (iii) Ground Station (GS); (iv) RADAR; (v) Long Range Camera; and (vi) Global Maritime Distress Safety and Security System (GMDSS).

Also, IMSCB has a Command and Control Center (PUSKODAL), which is located in Jakarta. This center is in charge of coordinating the data from each MRCC and RC. Some of the data can be accessed by both public and the stakeholders, such as: 
- data about warnings to ships that sail towards the areas with high waves,

- weekly data on security breaches and law enforcement at sea, either from within the country and abroad, prepared by CCC/IMSCB,

- daily AIS monitoring data performed by RCCs and MRCCs for the ships that cross the ALKI's regions,

- AIS integrase and Long-Range Camera--based data that are used both to detect violations at sea and to detect maritime security, containing data about both cruise ships that are on sail and about the wave height forecast information and weather in Indonesian waters.

The last data is one of IMSCB's public services, all of which are published by IMSCB's portal, called Indokamla.

With the implementation of NMIC, it is expected that the negative view of various parties at home and abroad regarding maritime security in Southeast Asia will change, particularly in the AKLI. The reason is that NMIC is predicted to provide accurate and actual data regarding security in both two areas which, in turn, will bring direct influences on efforts to create security and stability and will eventually affect the globalization. Also, other important information, as adopted by the US National Strategy for Maritime Security, which would be covered in NICM, is the information relating to six (6) different spectrums of interest that can uphold the national policy. Moreover, the role of NIMC will be more significant in the future, particularly when it is associated with the prioritized defense and security sector of IMSCB's Master Plan 2015/2019 of item 6 concerning the priority of border areas as outlined in item 1 of RPJM 2015/2019 about the strengthening of the monitoring stations in Aceh, Natuna, Tarakan, Bitung, Kupang and Karang Asem, and the areas where fleet and Tramper KIA go through, particularly in Ambon and Natuna.

\section{The Mystery of Black Box}

Knowledge in an institution such as IMSCB can only be generated through a sphere of mind, that is, the mind that is capable of creating a 'distance' to the surrounding worlds, of the so called 'ontological' mind, where a researcher as a 'subject' observes nature as an 'object' of knowledge. Hence, there is no 'knowledge' in the 'mythical' mind, where there is no 
a clear distance between man and nature. As remarked by van Peursen, "... a man constructs a certain distance in front of a confronted object; the subject posits himself/herself outwardly and is face to face with the object; it is only in this way that he or she can observe, delimit and explain the object through some clear explanations" (van Peursen 1976, 61)

Within the sphere of 'ontological' mind, a researcher posits his or her mind and consciousness as a "center of the world", the mind that has an exclusive power and authority to produce knowledge about their surroundings, including knowledge about technology. This is what is called 'anthropocentrism', a tendency that posits men as a "center" or "subject" of the surrounding external world. In supporting this anthropocentrism, Descartes decisively distinguishes a res cogitans-a thinking subject, consciousness, experience and mind as the center of the world; and a res extensa-the world of objects, matters, substances, body, physic, plants, animals, stones and planets, all the physical worlds, all things received, as externality of the human mind (Tarnas 1996, 277).

In term of the use of a technology in an institution such as IMSCB, "distancing" is an "active will" that motivates one to understand the objective world, by exploring and generating certain knowledge about the technology. Yet, as the world of technology itself is incessantly moving and dynamically changing-usually in an exponential way- "distancing" must be understood as a never-ending process. It is in this context that the concept of "self-consciousness" is deemed necessary for a researcher, which is uninterruptedly moving, moved, or make moves towards a teleologicaluniversal end of human progress. However, the growth of knowledge in an institution can only be made through the improvement of the quality of subjectivity, that is, through a reciprocal process of externalization of mind and consciousness through a "creative world of objects" supported by a model of mind "thesis-anti thesis-synthesis" and the internalization of the value of the objects that produce a meaningful life world (Hegel 1977, 118-19).

Nevertheless, the world as an 'object' of knowledge is not static; it is constructed not only by the principles of "certainty", "finiteness", "determination" and "order", but also by the principles of "uncertainty", "infiniteness", "indeterminacy" and "disorder". The architecture of the world is constructed by a principle of "chaos". However, as remarked by Michel Serres in Genesis, through a proper management, a disorder can be changed into order (Serres 1999, 109). Knowledge is an enterprise of 
changing a disorder to an order, an enterprise of exploring all "possibilities" or "possible worlds", as remarked by Serres:

" the philosopher is no longer right or rational, he protects neither essence nor truth.It is the function of the politician to be right and rational, it is the function of scientist to be right and rational; there are plenty of functionaries of the truth as it is, without adding more, the philosopher does not wrap himself up in truth as in breastplate or shield, he does not sing nor does he pray to allay nocturnal fears, he wants to let the possible roam free. Hope is in these margins, and freedom" (Serres 1999, 23)

It can be inferred from the above quotation that it is in the chaotic situation-in the "margins" between things and nothing, between order and chaos, between knowledge and unstructured mind-that we can talk about the "mystery", "the unknown" or the "black box". The "black box"-in the specific meaning of the word-is a mechanism that blocks our scientific mind to understand the complexity of things, because it is captured in the relation of "input and output" of the things. The black box refers to ". . . the way scientific and technical work is made invisible by its own success. When a machine runs efficiently, when a matter of fact is settled, one need to focus only on its inputs and outputs and not on its internal complexity" (Latour 1999, 304). Black box is a paradox, in which more successful things-science and technology-are more vaguely or blur its 'truth' in our eyes. Black box could be an object, product, technology, event or abstract thing. In the context of IMSCB, black box is the blocking of the scientific mind from the complexity of technologies, such as ENC, GS, LRC, RADAR or GMDSS.

There are many "black boxes" in everyday life: a machine, a bridge, a tool, a hand phone, a computer or a chip. In IMSCB, the operators, managers or instructors may see a RADAR or LRC every day, yet they do not always recognize the complexity of structures comprising these devices. To "open" the black box means to investigate the complexity of knowledge, techniques, or technologies behind these devices. In the box (devices) there is a part, which consists of other parts, and so on. In contrast, to ignore black box means to let the self being incurious, apathetic or uninterested in the complexity of the thing behind the box-for example a RADAR-by merely being a passive "consumer" of its function and use values. Through a "semantic extension", the concept "black box" can be understood more 
widely in the sciences; technologies; natural events such as earthquake, Tsunami, flood; or social facts likes traffic jam, chaos or mass violence.

Nevertheless, a series of great natural events in Indonesia such as earthquakes, volcano eruptions, tsunami, floods; or big social events such as economic crisis, political transformation, mass violence, genocide, human trafficking, smuggling or piracy-all remain to be a set of black boxes, because there is no expert or specialist gathered; there is no new tool, machine, technology created to open the complexity of the events. In IMSCB, some high-tech devices have been introduced to solve the problem of smuggling or piracy, but the devices are 'frozen' in the mind of certain individuals or users, because there has been no serious effort to understand the complexity of knowledge behind the technology. In fact, the obligation of the scientific community in opening the black box is to try to find “. . .'hard facts', or 'highly sophisticated machines', or powerful theories', or 'indisputable evidence"” (Latour 1987, 139), as sets of explicit scientific knowledge.

Concerning the condition of science, Latour distinguishes two kinds of knowledge. First, there is a "science in the making", in which there are several attempts to open a black box and find complexity behind the box, to produce new knowledge, a theory, system, product or technology. Second, there is a "ready-made science", in which people are more interested in "consuming" existing concepts, theories, systems, products or technologies, and have no interests or motivations to "peep" through a "scientific hole" the complexity of concepts, theories, systems or knowledge in general, in order to produce a new one (Latour 1987, 13).

In an institution such as IMSCB, to let the black box remain closed means to block the will, desire, or mind to scientifically catch up with certain "theories", "facts" or "realities", thereby complexities remain untouchable. As major natural or social events such as earthquakes, volcano eruptions, tsunami, floods, mass violence, smuggling or piracy are neglected as "untouched facts", they have remained a set of facts incapable of being converted into a set of scientific knowledge. What has been missed in this situation is what is called by Csikszentmihalyia as 'flow', that is, ". . .the state in which people are so involved in an activity that nothing else seems to matter; the experience itself is so enjoyable that people will do it even at great cost, for the sheer sake of doing it.” (Chickzentmihalyi 1990, 4).

To put it differently, what is absent is a kind of 'conversion' from a "fact" to "knowledge". In fact, the scope of this conversion could be much wider: the 
conversion from "fact"-to "discourse"-to "knowledge"- to "expression"to "artifact". It is through this line that a fact is scientifically discussed or debated in a "scientific discourse" in seeking scientific knowledge, and is then converted into various "expressions" (plan, design, blue print), and are finally produced as artifacts (product, technology, machine). Latour calls this converting process 'translation', which refers to “... all the displacements through other actors whose mediation is indispensable for any action to occur" (Latour 1999, 311). A fact is translated into a discourse to produce knowledge and eventually an artifact. In term of IMSCB, 'translation' also means the conversion of certain natural or social facts such as smuggling or piracy, or technologies such as RADAR into scientific knowledge.

'Translation' can also mean a movement from one place to another, an activity of giving a new interpretation of reality, a fact or interest that guide us to a different direction. Through the movement, “...certain issues (such as that of the science budget ...) are now solidly tied to much larger ones (the survival of the country, the future of cars), and therefore they are tied indeed that threatening the former is tantamount to threatening the latter" (Latour 1987, 117). In the context of IMSCB, the main problem in the technological translation is the gap between culture (the level of knowledge of the staffs, operators or users) and technology (the level of technical complexity). As the result, the complexity of high-tech cannot be converted into a systematical knowledge that produce further knowledge or artifact. Here, the complexity has remained unrevealed.

At a national level, a set of facts such as earthquakes, volcano eruptions, tsunami, floods, mass violence, the rise of oil price or the scarcity of non-renewable fuel cannot be concluded, solved, or predicted because of the incapability of a scientific community such as that in Indonesia in producing related knowledge, policies, systems or artifacts demanded as parts of a proposed solution. In contrast, what has flourishingly grown is a kind of "popular discourse" about the issues in various electronic media, particularly television: talkshow, infotainment, gossips that cannot produce scientific knowledge or products. To put it differently, people are more enthusiastic to "gossip" rather than to "think" about the facts in a more systematic, deeper and more scientific way. As a result, the process of translation has been totally blocked.

Figure.1 Constraint in Translation 


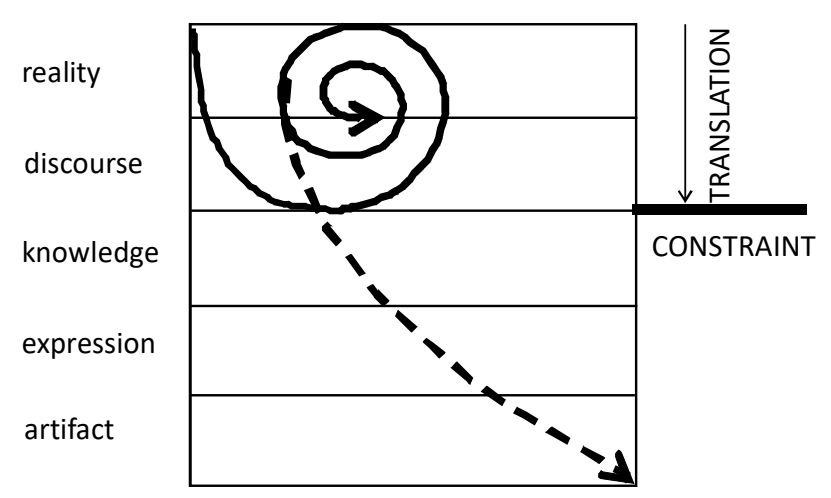

Far from being revealed, the mystery of black box remains a mystery, because there has hitherto no significant attempts to open it, no desire to accumulate knowledge from its mystery. To put it differently, the scientific mystery of natural disasters, economic crisis or social violence, remain a "mystery" due to the absence of serious, systematic, consistent and continuous scientific attempt to think, discuss, debate and propose relevant knowledge. The box will become durable if there is someone who tries to open it. As Latour remarked, “.. . the black box moves in space and becomes durable in time only through the actions of many people; if there is no one to take it up, it stops and falls apart no matter how many people may have taken it up for however long before." (Latour 1987, 137) In other words, knowledge will be "frozen" if there is no one to translate it into "expressions" (design, plan, blue print), and finally to make them manifest in the form of "artifact" (product, technology, infrastructure).

\section{Technoscience and Technoculture}

There have been several clues already provided in the previous discussion about the existence of "black box" in the discussion of science and technology in an institution such as IMSCB, that, the progress of science and technology highly depends on how deep and intensive the scientific encounter with black box is. Nevertheless, we have not discussed yet the relation between science, technology and culture in a certain institution. Concerning this relation, there are at least two different views. First, there is what is called "technological determinism", a view about technology as a determining "factor" in cultural changes. In contrast, there is a "cultural determinism", a view that sees culture as a "driving' factor of technological 
development (Kaplan and Manners 1972, 100).

Heidegger is one of the proponents of this technological determinism. For Heidegger, technology is a form of "revelation", that is, the uncovering of possible worlds (Heidegger and Lovitt 1977, 13), but, it is a form of "framing" at the same time. As Heidegger states, 'to frame' means “... the gathering together of that setting-upon which sets upon man, i.e., challenges him forth, reveals the real, in the mode of ordering, as standing-reserve. 'Enframing' means that way of revealing which holds sway the essence of modern technology and which is itself nothing technological" (Heidegger and Lovitt 1977, 20). In the context of IMSCB, the introduction of hightech devices in the context of solving the sea problems like smuggling and piracy can be seen as a form 'enframing', in the sense that it is a particular way of revealing the real.

Far from being the master of technology, a user is an existence of an entity, framed within the frame of technology, as can be seen in the use of "high-tech" devices in IMSCB. The user of a high-technology becomes a "possessed individual", when he or she "... no longer has any real existence, only a perspectival appearance as a site where all the referents converge and implode." (Kroker 1992, 5) This is as much to say that the user is not the master of a technology but its very target, user, or consumer. Hence, the possessed individual is controlled by a system (technological system, media system, economic system), and has no role what so ever to determine and change the system.

On the other hand, there is a view about "social determinism", that it is social structure that determines the growth of science and technology. One of these views states that reality-including language, knowledge, technology-is socially constructed, that "... our interaction with others in everyday life is constantly affected by our common participation in the available social stock of knowledge" (Berger and Luckmann 1991, 27). In the field of science and technology, there is a specific approach of science or technological studies, namely, "social studies of science' or "social construction of technology", to describe a social setting about how "... an idea spreads, a theory is accepted, or a machine is rejected" (Latour 1987, 141). In the context of the use of high tech in IMSCB, the development of science and technology and the production of knowledge are highly determined by the "social logics" of the institution itself.

In this context, Latour uses the concept "techno-science" to describe "reciprocal determinism" between social structure and relation (socio- 
gram) and technological structure and relation (techno-gram). Here, in the context of IMSCB as an institution, techno-science is constructed by two inseparable worlds; the first is the "inside" referring to the world of scientists, consultants, experts, instructors, operators and laboratories in the institution. The second is the "outside", that is, all strata of society as the subjects of the use of technology of the institution. Both worlds are, however, co-dependent one on the other in a paradoxical way. A certain technology can only work if the culture and knowledge level of the people "outside" is in line with the nature of the technology. In contrast, the "outside" cannot develop its own knowledge of technology without the existence of scientists and experts. Accordingly, "... the more esoteric a piece of techno-science is, the more exoteric the recruitment of people has to be" (Latour 1987, 158).

Since techno-science is highly dependent on the outside for its continuity, that is, wide social elements, it must have, in certain intensity, characters of "openness", "inclusivity" and "flexibility". As Latour remarks "... in the construction of techno-science we have to include all people and elements that have been recruited or are doing the recruiting, no matter how peculiar and unexpected they seem at first." (Latour 1987, 162). All the people have to be "interpellated" or "persuaded" to be self-involved in all technological problems, including their "controversies", for instance, about new rapid trains, sea bridge, oil drilling plans, etc. Hence, technoscience must produce so many possible forms of public communication as to be persuasive with more people in their controversies although it is impossible to make all the people aware of the importance of science and technology.

It is in this sense that Latour sees the importance of the functions of "mediation" as, first, a principle of symmetry among human actors (scientists) and non-human actors (tools, devices, instruments) in an institution as a form of "collectivity", bearing a social responsibility on scientific and technological progresses. Second, it functions as a composition of actions, through which an actor is given opportunity, empowered, supported or encouraged by other actors, to produce continuing co-actions. Third, it functions as "the folding of time-space", in which a certain technology can move forward or backward through timespace mediation. Fourth, it serves as the crossing of boundary between "signs" and "things", that is, a process of translation of not only definition and function but also change in "matter of expression", which is called a "delegation." (Latour 1999, 180-190) 
Unlike techno-science, techno-culture, though still closely related, refers to a "culture" grown as the result of the development of science and technology, both in 'passive' and 'active' senses. In the passive sense, technoculture in the context of an institution such as IMSCB is a study about the reception, representation, effect, value or meaning of technology in relation to the cultural life of the institution. Its objective is to find "the cultural" matters in the phenomena of technology such as ENC, GS, LRC, RADAR or GMDSS so as to get an understanding about a "new culture", for example information culture, digital culture, electronic culture, or cyber culture. Here, the development of high-tech digital technology has created an "electronic culture" (Druckrey 1996), a "visual culture" (Foucault and Mirzoeff 1998), or a "cyber culture" (Leary et al. 1994).

In the 'active' sense of technological development of an institution, technoculture is a study about cultural basis of technological development; it studies mentality, habit, habitus, social capital, cultural value, and 'fields' that are constructive for the development of science and technology. 'Field', according to Bourdieu, is "... a structured space of positions in which the positions and their interrelations are determined by the distribution of different kinds of resources or 'capital' (Thompson 1991, 14). In IMSCB, the structure of a field is understood as the distribution of invested 'capitals', which determines its success in a competition for certain knowledge position (Bourdieu 1993, 30). In the context of creativity or innovation, 'field' is a space of struggle for knowledge position, reception, recognition or domination.

It is in this field that the struggles of "trans-capital" are taking place: a "creative capital" as an individual who has strong inner-power to generate new ideas, concepts, systems or products (Csikszentmihalyi 1990, 4); "economic capital" as a form of material capital comprising all things with economic values; "symbolic capital" that comprises all non-material things that have certain cultural values (prestige, social status); "cultural capital" as a wider value system and meaning system (language, education, arts) (Harker et al. 2016, 13); and "social capital" as social network established among elements of a society (Boudrieu 1984, 106).

What has by now become very clear from the above discussion is that techno-science and techno-culture are two inseparable and mutualenforcing fields in creating a constructive space for the development of science and technology in an institution. Although the field of technoscience, according to Latour, is a symbiosis of scientists and society, 
human and non-human actors, techno-gram and socio-gram, the inside and outside, techno-science remains a study about science and technology itself. Techno-culture, on the other hand, is the field that studies not only the "effects' of technology on human beings as its users, but it is also a study about "man' as 'man'. Hence, in term of IMSCB, the main interest of techno-culture is eventually the study of all "human capacities" in their relation to the development of technology, particularly high-tech: their will, desire, mind, mentality, habitus, and creativity.

As far as interrelations of two fields in an institution are concerned, what we can see is a "cross-section" between fields. While the field of technoscience talks about 'hard facts' or 'highly sophisticated machines' (ENC, GS, LRC, RADAR or GMDSS), the field of technoculture talks about mentality, habitus, understanding, intelligence, will, character, value, ideology, and belief, generated through the technology. Clearly, there is an overlapping area between the fields, but one certain thing is that the progress of any institution is determined by its creative capability in managing these fields. Both fields are usually co-present for those whose creativity is a basic ideal that, by definition, can never be exhausted.

\section{Knowledge and Tradition}

Several clues have already been provided from the above discussion that both techno-science and techno-culture are the only "vehicles" capable of taking an institution to progress. Yet, we have no clue yet about the relation of techno-science and techno-culture to "tradition", a relation that is so far controversial as far as ideological basis is concerned. It is because, so far, the progress of technology and the value of a tradition are often posited as two opposite spheres. The main question is whether a tradition is a "stumbling block" for the progress of technology in an institution or, vice versa, the progress of science or technology, i.e., a "thread" for the continuity of a tradition. Far from being consensual, what we encounter here is a "controversy" or even "dispute" concerning the relation between science, technology and tradition.

From the viewpoint of techno-culture, objects of modern science exist in "nature", whereas a scientist, as a subject, lives in a "society" or "culture". Here, we have a contrast between "nature" and "culture". This view has two 
consequences. First, "scientific facts" and "technical artifacts" have to be seen differently from "culture" because both have a different value system. In other words, there is a separation between "objectivity" (efficiency) and "subjectivity" (value, feeling, desire); this is what makes techno-culture possible. Second, because modern science is oriented to the future and to continuously search for newness and progress, it must structurally create wider and bigger "distance" from tradition. In other words, modern science must reject and divert from all traditions (Latour 1999, 193).

However, no matter how strong this modern world view may be, there has been a recent tendency in the philosophy of science to attack this world view through what is called a "postmodern science". This science (or precisely sciences) is a serious challenge to a modern view of Enlightenment, according to which science is seen as a "universal endeavor" in seeking a "universal truth" about good life, in contrast to and separated from a "pseudo-science", which originated from various sources of traditions, myths, mysticism and religions (Nader 1996, 6). Thus, ethno-scientists, geographers, orethno-botanists, have recently brought to light a farming technology, resources management, pharmacology, navigation, irrigation system, food stuff and transportation inspired by what were previously labeled as indigenous knowledge; today, however, they have to be "equal" to all universal knowledge (Nader 1996, 7). In the context of the maritime culture in Indonesia, certain cultural traditions, myths or even mystics are still a great challenge for the introduction and implementation of hightechnology in some seawater areas, for example the myth of Nyi Roro Kidul.

This is, however, not to claim that science and technology can be in line with cultural traditions, myths or mysticisms. As Latour remarks, although science and technology are open spaces for elements of the past, including tradition, the orientation of science remains directed to the future, because science and technology must continually produce progress. This opening of space for tradition has two consequences. First, the development of science and technology is possible through the "melting" of subjects and objects, human actors and non-human actors. Second, through the "folding of time-space", the black boxes from the past can be part of the present discourse of science (Nader 1996, 193). In other words, we can no longer remember the past for the past shake, but to project it to the future.

As far as tradition is concerned, the main problem, according to Latour, is the concept of "change" itself, that is to say, the impact of change to 
tradition. On the one hand, objects, facts, realities as "objects" of science, are incessantly changing, both in an evolution or a revolution model. On the other hand, our understanding and interpretation of the objects, facts and realities are also incessantly changing (Latour 2007, 83). Not only are the objects of science incessantly moving and dynamically changing, our versions of knowledge about the objects are also changing. Concerning the change in science and technology, Latour proposes two related schemes.

The first scheme is a "teleportation scheme", which regards objects of science as both still and static, whereas a scientist as a subject exists in certain point between the past and present, depending on his/her point of view about the objects. The epistemological problem of knowledge is how to fill the "gap" between the subject and object or between the mind and nature, by cleverly positing two different positions - "the knowing subject' and "the known object"-in such a way that it is capable of generating a new idea or knowledge. The challenge here is, therefore, whether one is encouraged to "move forward", by bringing the "unmoving target" to the present context or situation, or by being seduced and pulled to the "aura" of the past. As Hackett states, "... the key question is to decide whether we move forward-toward the unmoving target of the object to be knownor backward-in which case we are thrown back to the prison of our prejudices, paradigms, or presuppositions (Hackett et al. 2008, 95). In the context of maritime culture, certain individuals, who are the subjects of the incapability of escaping from the "trap" of tradition or myth, which block their way from moving forward to the culture of high-tech.

The second is a "continuous scheme", in which objects of science are changing in a scientific discourse situation that is also changing. The main problem here is not to decide whether a statement moves forward or backward-through the relation of subject and object-but whether it moves forward or backward in time. In other words, the main problem of knowledge today is to build a continuous chain of knowledge to multiply cross-sections of statements, which make possible for retroactive decisions on whether we are right or wrong in our present business. Here, "to move forwards" means that we become a more "experienced", "knowing" and "sublime" person in terms of quality of collective, organized and institutionalized knowledge (Hackett et al. 2008, 95). In the case of IMSCB and the users of technology, the strong power of cultural myth is one of the main factors that hinder the growth of knowledge and the "move-forward" in term of scientific knowledge. 
Today's dilemma lies in how to integrate never-ending moves of "modern or post-modern knowledge" with a fixed "traditional knowledge, in other words, how to integrate a continuously changing knowledge into a "static", "repetitive" or "reproductive knowledge". Here, what we need is a specific meaning of the concept "change" itself. On the one hand, the enrichment of experience and the multiplicity of knowledge can only be achieved through a continuous process of explorations. On the other hand, the enrichment of culture through tradition can only be achieved through the continuous 'exploration' of tradition itself-not to repeat it-to invent "newness" of the tradition”.

\section{Techno-cultural Transformation}

As has by now become very clear from the above discussion, the relation between science, technology and institutional culture is not a linier or one-direction one. Instead, it is a two direction-reciprocal relation, in which both science-technology and institution interact with each other in a mutual or reciprocal model. Despite the existence of two oppositional views regarding this relation, there is a "third way" view that tries to mediate these two points of views, namely a view about 'soft determinism', according to which technology is seen as changing culture but at the same time is constructed by it. In other words, a technology offers a set of new cultural values, but on the other hand, some cultural values in the institution give specific orientation for technology, as consistently shown by Latour.

To put the question differently, what is more important is how to build a "bridge" between the territory of science-technology and a territory of culture. In a social situation in which science-technology is socially separated from culture, the role of mediation or "communicator" is played by an elite "middleman', that is, a journalist of science and technology. In contra-distinction, in the scheme of techno-science proposed by Latour, middleman is no longer needed, because the scientists or technologists themselves are now "public intellectuals", who are capable of directlyor without mediation-communicating with public. As Brockman states, "the role of the intellectual includes communicating. Intellectuals are not just people who know things but people who shape the thoughts of their generation. An intellectual is a synthesizer, a publicist, and a communicator" (Williams and Brockman 1995, 19). 
Figure.2 Techno-science and techno-culture relationship

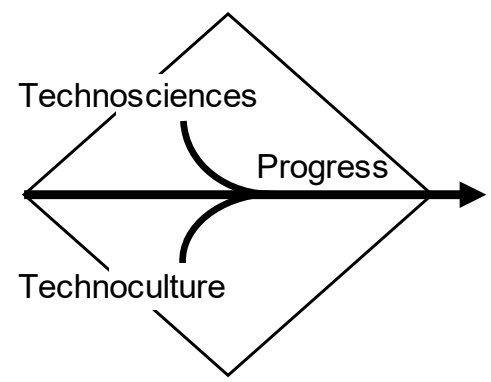

The above diagnosis leads to a tentative conclusion that the cultural transformation is a way of building awareness toward knowledge in a certain institution, which can only be performed through a comprehensive and integrative reorganization of the 'inside' world of scientists and the 'outside' world of society in an integrative "techno-scientific-culture". On the one hand, it is important to firstly build the 'inside' world with scientists as an inseparable world from the outside, along with the laboratories, tools, paradigms, methods and scientific cultures. on the other, it is important to build 'scholarship', that is, an integrative endeavor of rational, systemic and creative investigation about a certain topic, which gives benefits to a society. Yet, scholarships have a politic side, because it "... depends on the freedom to think, to inquire, and to express one's unique views and perspectives" (Hatch 2005, 15). On the other hand, internally, it must be self-reflective, particularly about the effect or benefit of the scholarships given to the society. As McKinney states, scholars must “... do things such as reflect on their teaching, use class room assessment techniques, discuss teaching issues with colleagues, try new things, and read and apply the literature on teaching and learning in their discipline" (McKinney 2010, 9).

\section{Conclusion}

On the other side of the spectrum, it is highly important to build "public awareness" about the role, function, significance and benefit of science and technology for humanity. Concerning the public or society itself, there are at least two cultural aspects that particularly determine the building of public awareness, namely, 'values'. If values are understood as an intrinsic and normative quality of an individual or a group that determines actions and are honored as good things, in terms of the development of science 
and technology, we can talk about a "supportive" and "unsupportive values" (Harrison and Huntington 2000). The values such as openmindedness, competitiveness, accountability, being visional (Porter 2000, 22), showing appreciation and respect for innovation (Inglehart 2000, 83) are among supportive values that encourage the development of science and technology. The progress of science and technology is only possible if they are highly appreciated.

\section{References}

\section{Book and Chapters in Book}

Berger, P.L. and Luckmann, T., 1991. The social construction of reality: A treatise in the sociology of knowledge (No. 10). Penguin Uk.

Boudrieu, P., 1984. Distinction: A Social Critique of the Judgement of Taste. Harvard University Press.

Bourdieu, P., 1993. The field of cultural production: Essays on art and literature. Columbia University Press.

Csikszentmihalyi, M., 1990. Flow: The Psychology of Optimal Experience. HarperPerennial, New York.

Druckrey, T., 1996. Electronic culture: technology and visual representation. Aperture

Foucault, M. and Mirzoeff, N., 1998. The Visual Culture Reader. London: Routledge

Hackett, E.J., Amsterdamska, O., Lynch, M. and Wajcman, J., 2008. The handbook of science and technology studies (No. 3rd). The MIT Press.

Harker, R., Mahar, C. and Wilkes, C. eds., 2016. An introduction to the work of Pierre Bourdieu: The practice of theory. Springer.

Harrison, L.E. and Samuel, P., Huntington. 2000. Culture Matters: How Values Shape Human Progress. Corruption Culture and Markets. edited by Seymour Martin Lipset, and Gabriel Salman Lenz, pp.11225 .

Hatch, T., 2005. Into the Classroom: Developing the Scholarship of Teaching and Learning. Jossey-Bass, An Imprint of Wiley. 10475 Crosspoint Blvd, Indianapolis, IN 46256.

Hegel, G.W.F., 1977. Phenomenology of Spirit. Oxford: Oxford University Press. 
Heidegger, M. and Lovitt, W., 1977. The question concerning technology, and other essays. New York: Harper \& Row.

Inglehart, R., 2000. Culture and democracy. in Culture matters: How values shape human progress, pp.80-97.

Kaplan, D. and Manners, R.A., 1972. Culture theory. Prentice Hall.

Kroker, A., 1992. The possessed individual: Technology and the French postmodern. New World Perspectives.

Latour, B., 1987. Science in action: How to follow scientists and engineers through society. Harvard university press.

Latour, B., 1999. Pandora's hope: essays on the reality of science studies. Harvard university press.

Latour, B., 2007. A Textbook Case Revisited-Knowledge as mode of existence. In Hackett, E.J., Amsterdamska, O., Lynch, M. and Wajcman, J., 2008. The handbook of science and technology studies (No. 3rd). The MIT Press.

Leary, T., Horowitz, M. and Marshall, V., 1994. Chaos \& cyber culture. Grupo Editorial Norma.

McKinney, K., 2010. Enhancing learning through the scholarship of teaching and learning: The challenges and joys of juggling (Vol. 139). John Wiley \& Sons.

Nader, L., 1996. Naked science: anthropological inquiry into boundaries, power, and knowledge. New York: Routledge.

Porter, M.E., 2000. Attitudes, values, beliefs, and the microeconomics of prosperity. in Culture Matters. New York: Basic Books, 2000, pp.1428.

Serres, M., 1999. Genesis. Michigan. The University of Michigan Press

Tarnas, R., 1996. The passion of the Western mind: Understanding the ideas that have shaped our world view (Vol. 218). Random House.

Thompson, John B., 'Intoduction', in Bourdieu, P., 1991. Language and symbolic power. Harvard University Press.

van Peursen, C.A. and Hartoko, D., 1976. Strategi kebudayaan. Penerbitan Kanisius.

Williams, G.C. and Brockman, J., 1995. The Third Culture: Beyond the Scientific Revolution 